\title{
Review of Pharmaceutical Applications of N-Methyl-2-Pyrrolidone
}

\author{
Abolghasem Jouyban ${ }^{1}$, Mohammad A. A. Fakhree ${ }^{2}$, and Ali Shayanfar ${ }^{3}$ \\ ${ }^{1}$ Drug Applied Research Center and Faculty of Pharmacy, Tabriz University of Medical Sciences, Tabriz, Iran. \\ ${ }^{2}$ Biotechnology Research Center, Tabriz University of Medical Sciences, Tabriz, Iran. \\ ${ }^{3}$ Liver and Gastrointestinal Diseases Research Center, Tabriz University of Medical Sciences, Tabriz, Iran.
}

Received, September 9, 2010; Revised, November 2, 2010; Accepted, November 11, 2010, Published, November 11, 2010.

\begin{abstract}
N-Methyl-2-pyrrolidone (NMP) is a very strong solubilizing agent that has important applications in different fields of industry. This review presents NMP's physicochemical characteristics, its applications - especially in the pharmaceutical sciences, pharmacokinetics and toxicity. The characteristics of NMP, such as physicochemical properties, solubilization efficacy, toxicity, and adverse effects, are compared with those of other common solvents used in pharmaceutical industries. This review shows that NMP is an acceptable pharmaceutical solvent and that its efficacy, toxicity, and side effects are comparable with those of other common solvents.
\end{abstract}

\section{INTRODUCTION}

1-Methyl-2-pyrrolidone is a liquid, also called by several other names, such as 1-methyl-2pyrrolidinone, 1-methyl-5-pyrrolidinone, 1methylazacyclopentan-2-one, 1-methylpyrrolidinone, 1-methylpyrrolidone, methylpyrrolidone, N-methyl-2-pyrrolidinone and $\mathrm{N}$ methyl-2-pyrrolidone (NMP). It is a solvent with high power for solubilizing chemicals and pharmaceutical agents. It is a product of the petroleum industry and can be recycled by distillation and extraction with water $(1,2)$. NMP is a biodegradable solvent therefore, environmental contamination considerations are fewer in its applications (3). It is used in different fields and is considered a safe solvent (4). In a recent study, it has been isolated from a marine sponge, which shows that it may be biosynthesized (5).

\section{PHYSICOCHEMICAL PROPERTIES}

In the pharmaceutical sciences, water is the most common solvent; however, organic solvents are also used. Table 1 shows a summary of physicochemical properties of the common organic solvents that have been reported as cosolvents in the literature related to pharmaceutical sciences (6), along with the properties of NMP. NMP belongs to the group of aprotic solvents, is a slightly yellow clear liquid, and is miscible with water; low molecular-weight alcohols; ketones; polyethylene glycols; and other solvents such as ethyl acetate, chloroform, and benzene. It has low volatility and low flammability, with the necessary solubilization power to make it a suitable solvent in different fields of applications. It does not form an azeotropic mixture with water (7).

The mechanism of solubilization of drugs by NMP is ambiguous, and there are various theories for the same, including its action as a cosolvent (8), complexing agent (9), and surfactant (10). Recently, Sanghvi et al. investigated the solubilization mechanism of NMP and concluded that it acts as a cosolvent and complexing agent simultaneously (11). The NMP molecule (Figure 1) has nonpolar carbons, which can weaken the hydrogen-bonded structure of water, thus enabling it to act as a cosolvent. In addition, the presence of a large planar nonpolar region can lead to hydrophobic interactions between NMP and drugs (11).

Apart from the useful properties of NMP, some deleterious effects have also been found. Steel parts of apparatuses used in the presence of this solvent have been reported to undergo a corrosive reaction at temperatures above $300^{\circ} \mathrm{C}$, which restricts its applications at higher temperatures in a metal-containing setup $(12,13)$.

\section{INDUSTRIAL APPLICATIONS}

NMP has been used in different fields of industrial applications, including electronics, petroleum, paint, textiles, rubber, chemical, polymer, and pharmaceutical industries; various syntheses; and different analytical methods (15). However, the main emphasis of this review is on its pharmaceutical aspects and applications.

Corresponding Author: Dr. A. Jouyban, Faculty of Pharmacy, Tabriz University of Medical Sciences, Tabriz 51664, Iran. Email: ajouyban@hotmail.com 


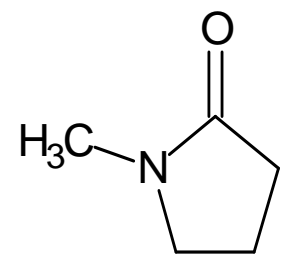

Figure 1. Chemical structure of N-methyl-2-pyrrolidone (NMP)

\section{PHARMACEUTICAL APPLICATIONS}

\section{Solvent or Cosolvent}

NMP is one of the main pharmaceutical cosolvents (16), and it acts as a very strong solubilizing agent; it is a solubilizing excipient used in parenteral and oral medications (4). It is an important solvent used in the extraction, purification, and crystallization of drugs $(17,18)$. A few commercial pharmaceutical products containing NMP, which are all nonaqueous formulations, are currently available in the market. Leuprolide acetate (Sanofi-aventis, Quebec, Canada) is used for the suppression of gonadal sex-hormone production in the treatment of malignant neoplasms of the prostate and is formulated as a solution composed of $55-66 \%$ NMP and 34-45\% poly(DL-lactide-co-glycolide) for use as a controlled-release gel for subcutaneous injection. After injection, NMP diffuses away from the injection site, providing a depot of drug that is released over a period of 1 to 6 months. Doxycycline hyclate (Atrix Laboratories, Colorado, USA) gel is composed of $100 \mathrm{mg} / \mathrm{mL}$ doxycycline hyclate in NMP with $37 \%$ poly(DL-lactide) and is used for subgingival administration in the form of a seven-day controlled-release system (4). Florfenicol (Intervet/Schering-Plough Animal Health, Boxmeer, The Netherlands) IV solution and doxycycline gel (Pfizer Animal Health, Quebec, Canada) for the treatment and control of periodontal diseases contain NMP and are used in veterinary medicine (11). NMP can be used in parenteral formulations of drugs, because in addition to its excellent solubilizing power, it has low viscosity, which is a critical parameter in using fine-gauge needles or microcatheters (4). Wei et al. have patented a novel form of carvedilol that is solvated with NMP and have named it "carvedilol pharmasolve solvate". The conventional form of the drug is prescribed twice a day, whereas the novel form can be orally prescribed as a unit dose/day or may be administered in other dosage forms (19). In addition to carvedilol, hydrochlorothiazide can also form a solvate with NMP. This solvate is composed of one hydrochlorothiazide and two molecules of NMP (20). Finally, NMP is used as a solubilizing agent for increasing the uptake of poorly soluble drugs such as itraconazole (9). Systematic investigations have been conducted on the solubility of clonazepam, diazepam, lamotrigine, phenobarbital, pioglitazone hydrochloride, estrogen, and griseofulvin in water + NMP mixtures $(11,21,22)$. Table 2 shows the solubilization efficacy of NMP for some drugs, in comparison with ethanol and propylene glycol. To investigate the solubilization efficacy of the cosolvents, two definitions are proposed in literature; the solubilization power, defined by Yalkowsky $(\sigma)(23)$; and a definition derived from the Jouyban-Acree model ( $\omega)$ (24), represented as following:

$$
\begin{gathered}
\sigma=\log \left(\frac{X_{c}}{X_{w}}\right) \\
\omega=\frac{\log \left(\frac{X_{m, \text { max }}}{X_{w}}\right)}{f_{2, \text { max }}}
\end{gathered}
$$

Here, $X_{c}$ and $X_{w}$ are the solubilities of a drug in the cosolvent and water; $X_{m, \max }$ is the maximum solubility of the drug in water + cosolvent mixture; and $f_{2, \max }$ is the volume fraction of the cosolvent providing the maximum solubility. Usually, in pharmaceutical applications, cosolvents are used up to a fraction of 0.5 ; hence, another solubilization power has been defined by Yalkowsky's group (23) as follows:

$$
\sigma_{0.5}=\log \left(\frac{X_{0.5}}{X_{w}}\right)
$$

where $X_{0.5}$ is the solubility of a drug in a cosolvent fraction equaling 0.5 . 
Table 1. Properties of seven pharmaceutically applicable solvents: Melting Point (MP), Boiling Point (BP), Flash Point (FP), Refractive Index (RI), Surface Tension (ST), Viscosity ( $\eta$ ), Density ( $\rho$ ), Solubility Parameter (SP), Vapor Pressure (VP), and Molecular Weight (MW).

\begin{tabular}{|c|c|c|c|c|c|c|c|}
\hline $\begin{array}{l}\text { Property } \\
\text { (Reference) }\end{array}$ & Ethanol & Dimethylacetamide & Dimethylsulfoxide & Glycerol & Isopropanol & NMP & Propylene glycol \\
\hline $\begin{array}{l}\text { Chemical Abstracts } \\
\text { Service no. ( } 7 \text { ) }\end{array}$ & $64-17-5$ & $127-19-5$ & $67-68-5$ & $56-81-5$ & $67-63-0$ & $872-50-4$ & $57-55-6$ \\
\hline $\begin{array}{l}\text { Simplified } \\
\text { molecular input } \\
\text { line entry } \\
\text { specification or } \\
\text { SMILES (7) }\end{array}$ & $\mathrm{C}(\mathrm{C}) \mathrm{O}$ & $\mathrm{C}(\mathrm{N}(\mathrm{C}) \mathrm{C})(\mathrm{C})=\mathrm{O}$ & $\mathrm{S}(\mathrm{C})(\mathrm{C})=\mathrm{O}$ & $\mathrm{C}(\mathrm{CO})(\mathrm{CO}) \mathrm{O}$ & $\mathrm{C}(\mathrm{C})(\mathrm{C}) \mathrm{O}$ & $\mathrm{C} 1(\mathrm{~N}(\mathrm{CCC} 1) \mathrm{C})=\mathrm{O}$ & C((C@@H)(C)O)O \\
\hline International & $\mathrm{InChI}=1 /$ & $\operatorname{InChI}=1 /$ & $\mathrm{InChI}=1 /$ & $\mathrm{InChI}=1 /$ & $\mathrm{InChI}=1 /$ & $\mathrm{InChI}=1 /$ & $\mathrm{InChI}=1 /$ \\
\hline Chemical Identifier & $\mathrm{C} 2 \mathrm{H} 6 \mathrm{O} /$ & $\mathrm{C} 4 \mathrm{H} 9 \mathrm{NO} /$ & C2H6OS/ & $\mathrm{C} 3 \mathrm{H} 8 \mathrm{O} 3 /$ & $\mathrm{C} 3 \mathrm{H} 8 \mathrm{O} /$ & C5H9NO/ & $\mathrm{C} 3 \mathrm{H} 8 \mathrm{O} 2 /$ \\
\hline (InChI; 7) & $\begin{array}{c}\mathrm{c} 1-2-3 / \\
\text { h3H,2H2,1H3 }\end{array}$ & $\begin{array}{c}\text { c1-4(6)5(2)3/ } \\
\text { h1-3H3 }\end{array}$ & $\begin{array}{l}\mathrm{c} 1-4(2) 3 / \\
\mathrm{h} 1-2 \mathrm{H} 3\end{array}$ & $\begin{array}{l}\text { c4-1-3(6)2-5/ } \\
\text { h3-6H,1-2H2 }\end{array}$ & $\begin{array}{c}\mathrm{c} 1-3(2) 4 / \\
\mathrm{h} 3-4 \mathrm{H}, 1-2 \mathrm{H} 3\end{array}$ & $\begin{array}{c}\text { c1-6-4-2-3-5(6)7/ } \\
\text { h2-4H2,1H3 }\end{array}$ & $\begin{array}{c}\mathrm{c} 1-3(5) 2-4 / \\
\text { h3-5H,2H2,1H3 }\end{array}$ \\
\hline $\mathrm{MP}(\mathrm{K})(14)$ & 159 & 253 & 291.5 & 291 & 183.5 & 249 & 213 \\
\hline $\mathrm{BP}(\mathrm{K})(14)$ & 351 & 438 & 462 & 563 & 356 & 475 & 460 \\
\hline FP (K) (14) & 286 & 343 & 368 & 433 & 285 & 368 & 372 \\
\hline RI (14) & 1.359 & 1.436 & 1.476 & 1.4746 & 1.375 & 1.468 & 1.431 \\
\hline$\eta(\mathrm{cP})(14)$ & 1.08 & 0.92 & 2.00 & 1200.00 & 2.00 & 1.80 & 54.00 \\
\hline$\rho(\mathrm{g} / \mathrm{cm}-3)(14)$ & 0.789 & 0.945 & 1.101 & 1.261 & 0.786 & 1.03 & 1.0362 \\
\hline $\mathrm{SP}(\mathrm{MPa} 1 / 2)(14)$ & 13.4 & 11.0 & 13.0 & 21.1 & 11.5 & 11.0 & 14.8 \\
\hline $\log P(7)$ & -0.31 & -0.77 & -1.35 & -1.76 & 0.05 & -0.38 & -0.92 \\
\hline VP (mm Hg) (7) & 59.3 & 2 & 0.61 & 0.000168 & 45.4 & 0.345 & 0.129 \\
\hline Formula (7) & C2-H6-O & C4-H9-N-O & C2-H6-O-S & $\mathrm{C} 3-\mathrm{H} 8-\mathrm{O} 3$ & $\mathrm{C} 3-\mathrm{H} 8-\mathrm{O}$ & C5-H9-N-O & $\mathrm{C} 3-\mathrm{H} 8-\mathrm{O} 2$ \\
\hline MW (7) & 46.07 & 87.12 & 78.13 & 92.09 & 60.10 & 99.13 & 76.09 \\
\hline
\end{tabular}

The data in Table 2 show that NMP has better $\sigma$ and $\omega$ values than ethanol and propylene glycol, which indicate that it is a good candidate for use in pharmaceutical formulations.

\section{Penetration Enhancer}

NMP is a chemical penetration enhancer $(27,28)$ and is used for enhancement of transdermal delivery of hydrophilic and hydrophobic drugs from an aqueous phase (29). It is used as a good enhancer in topical formulations of griseofulvin, delivering effective concentrations of the drug (30); it is also used in combination with other enhancers, such as 1-dodecylazacycloheptan-2-one (Azone), for improvement in skin permeation of fluoxetine hydrochloride (31). The effects of chemical enhancers in the transdermal delivery of lidocaine have been investigated, and NMP is a good enhancer of hydrophobic molecules, such as lidocaine, for transdermal delivery. Combination of NMP and isopropyl myristate may have utility in the delivery of other hydrophobic molecules (32). 
Table 2. Comparison of the solubilization powers of NMP, ethanol, and propylene glycol

\begin{tabular}{|c|c|c|c|c|c|c|c|c|c|}
\hline \multirow[b]{2}{*}{ Drug } & \multicolumn{3}{|c|}{$\omega$} & \multicolumn{3}{|c|}{$\sigma$} & \multicolumn{3}{|c|}{$\sigma_{0.5}$} \\
\hline & Ethanol & $\begin{array}{l}\text { Propylene } \\
\text { glycol }\end{array}$ & NMP & Ethanol & $\begin{array}{l}\text { Propylene } \\
\text { glycol }\end{array}$ & NMP & Ethanol & $\begin{array}{l}\text { Propylene } \\
\text { glycol }\end{array}$ & $\begin{array}{l}\mathrm{NM} \\
\mathrm{P}\end{array}$ \\
\hline Diazepam & 3.28 & 2.45 & 3.93 & 2.78 & 2.45 & 3.93 & 2.05 & 1.28 & 2.35 \\
\hline Clonazepam & 2.43 & 2.29 & 3.85 & 2.10 & 2.29 & 3.85 & 1.66 & 1.01 & 2.13 \\
\hline Phenobarbital & 2.22 & 2.08 & 3.18 & 2.04 & 2.08 & 2.64 & 1.25 & 1.03 & 2.25 \\
\hline Lamotrigine & 2.22 & 2.45 & 1.90 & 1.28 & 2.45 & 1.90 & 1.40 & 1.24 & 1.61 \\
\hline Pioglitazone- $\mathrm{HCl}$ & 3.14 & 2.24 & 3.39 & 1.51 & 2.21 & 2.86 & 1.56 & 1.86 & 1.59 \\
\hline Estrone & ND & ND & ND & ND & ND & ND & 2.82 & 1.99 & 3.00 \\
\hline Griseofulvin & ND & ND & ND & ND & ND & ND & 2.54 & 1.66 & 2.62 \\
\hline
\end{tabular}

Solubility data of diazepam, clonazepam, and lamotrigine in ethanol + water mixtures taken from reference 25; phenobarbital in ethanol + water taken from references 82 diazepam, clonazepam, phenobarbital, and lamotrigine in propylene glycol + water and $\mathrm{NMP}+$ water mixtures taken from references 26 and 22, respectively; pioglitazone hydrochloride in ethanol + water, propylene glycol + water, NMP + water taken from reference 21; and estrone and griseofulvin in ethanol + water, propylene glycol + water, NMP + water taken from reference 11. Solubility data of estrone and grisolfulvin in cosolvent + water mixtures were reported up to volume fractions of $50 \%$, so $\omega$ and $\sigma$ are not calculated.

NMP can be used as a permeability enhancer for both hydrophilic and lipophilic drugs in ophthalmic drug-delivery systems. It is a nonirritant compound at concentrations of $0-10 \%(\mathrm{v} / \mathrm{v})(33,34)$. Recently, NMP has been used in a nanoemulsion system for the transdermal delivery of granisetron hydrochloride (35). Examples of drugs that their topical formulations may contain NMP as an absorption enhancer include, griseofulvin (30), fluoxetine $\mathrm{HCl}(31)$, lidocaine (32), granisetron $\mathrm{HCl}$ (35), insulin (36), estradiol $(37,38)$, levonorgestrel (37), bupranolol (39), spantide II (40), luteinizinghormone-releasing hormone (41), ibuprofen (42), flurbiprofen (42) and morphine- $\mathrm{HCl}$ (43).

\section{Other Applications of NMP in the Pharmaceutical Area}

NMP is used in pharmaceutical analysis. For example, an additional syringe wash with NMP can improve the consistency of injections using gas chromatogaraphy syringes by improving peak symmetry and reproducibility (44). This solvent can

improve bone morphogenetic protein (BMP) activity by enhancing the kinase activity of the $\mathrm{BMP}-$ receptor complex and has been proposed as a potent drug for bone-tissue regeneration (45). NMP is also used to enhance delivery of hypericin, which is an antitumor, photodynamic, and photodiagnostic agent with very low water solubility, into solid tumors and enhances the photodynamic therapeutic effects of hypericin on human bladder carcinoma
(46). Finally, NMP can play important roles in chemical reactions, such as hydrolysis, oxidation, condensation, conversion with chlorinating agents, polymerization, o-alkylation, and related reactions (15). Recently, NMP has been used as a reducing agent to synthesize metal nanoparticles (47). It can also be used in preparing nanotubes (48).

\section{ABSORPTION, DISTRIBUTION, METABOLISM, AND EXCRETION PROPERTIES}

\section{Absorption}

NMP is easily absorbed from the human skin gastrointestinal and respiratory tracts (49). The permeability of commercial solvents through human skin has been investigated in a study, and the permeability rate of NMP was found to be higher than that of other solvents (50).

\section{Distribution}

NMP is quickly distributed in most organs, with a relatively high concentration in the sexual organs. Repeated exposures may be one of the reasons for infertility (49). The volume of distribution ( $\mathrm{Vd}$ ) of NMP is $0.7 \mathrm{~L} / \mathrm{kg}$, and the half-life of unchanged NMP in the plasma after oral or dermal administration and inhalation exposure are 9-12 h and $4 \mathrm{~h}$, respectively (51).

\section{Metabolism}

NMP is hyroxylated to 5-hydroxy- $N$-methyl-2pyrrolidone (5-HNMP) by the isoform $1 \mathrm{E}$ of 
cytochrome P450 (CYP1E) and oxidized to $\mathrm{N}$ methylsuccinimide (MSI); MSI is then hyroxylated to 2-hydroxy- $N$-methylsuccinimide (2-HMSI). 2Pyrrolidone is reported as another metabolite of NMP (52, 53). Figure 2 shows the metabolic pathway of NMP (53).

\section{Elimination}

The main route of excretion of NMP and its metabolites, such as 5-HNMP, is by the kidneys through urine (49). Elimination of NMP is a saturable process, and unchanged NMP is intensively reabsorbed by the glomeruli (51).

\section{TOXICITY}

Knowledge about the toxicity and side effects of NMP in humans and animals is useful, and this information is required by regulatory authorities to approve any drug formulation containing NMP. Numerous studies have been carried out on living organisms, including bacteria (7), human cell lines (7), mice $(54,55)$, rats (54-62), dogs (63), and humans (64-71). This solvent is classified as a teratogenic compound in PubChem, and twelve bioassays reported its effects on living organisms. Studies on mice, rats, dogs, and human subjects yielded conflicting results and are described in more detail in this review. Furthermore, NMP has significant cardiovascular toxicity, and the arterial pressure change induced after interarterial infusion is more than that caused by other solvents (72).

\section{Bioassays}

According to the data available at PubChem, three NMP-activity bioassay reports are found regarding its carcinogenic potency on MultiCellCall, SingleCellCall, and mouse subjects. However, no carcinogenic potency is reported for rat and salmonella; moreover, it is reported to have anticancer activity toward seven types of cancerous subjects (73).

\section{Animal Toxicity Studies}

A study conducted in 1982 on the teratogenicity of NMP on rats when administered through the skin has concluded that doses of 75 and $235 \mathrm{mg} / \mathrm{kg}$ per day are not teratogenic; however, a dose of 750 $\mathrm{mg} / \mathrm{kg}$ has been found to cause maternal abnormalities in rats (56). Becci and coworkers have studied the chronic toxicity of orally administered NMP at doses of 25, 79, and 250 $\mathrm{mg} / \mathrm{kg}$ per day for 13 weeks on dogs.

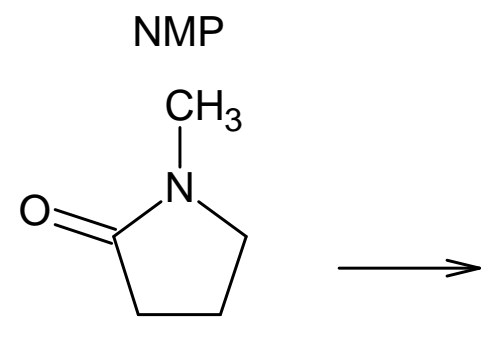<smiles>CN1C(=O)CCC1O</smiles><smiles>C1CC1</smiles><smiles>CN1C(=O)CC(O)C1=O</smiles>

2-HMSI<smiles>CN1C(=O)CCC1=O</smiles>

MSI

Figure 2. The metabolites of NMP 
They reported no significant changes in physiological signs, except a dose-dependent decrease in body weight and increase in platelet count in both male and female dogs, in addition to a decrease in blood cholesterol in male dogs (63). In another study on rats by Lee and coworkers, it has been shown that NMP has no teratogenicity when inhaled at doses of 0.1 and $0.36 \mathrm{mg} / \mathrm{L}$ for $6 \mathrm{~h} /$ day; and no toxicity at doses of 0.1 and $0.5 \mathrm{mg} / \mathrm{L}$ for 6 $\mathrm{h} /$ day, 5 days/week for 4 weeks; however, in rats that had an intake of $1 \mathrm{mg} / \mathrm{L}$, lethargy, respiratory difficulty, and excessive mortality has been found, in association with focal pneumonia, bone-marrow hypoplasia, and atrophy of the lymphoid tissue in the spleen and thymus, which are all reversible after 2 weeks of survival. Doses of 0.04 or $0.4 \mathrm{mg} / \mathrm{L}$ for $6 \mathrm{~h} /$ day, 5 days/week for 2 years on male rats show no significant life-shortening effects (57). After exposure of pregnant rats to 150 parts per million (ppm) of NMP for $6 \mathrm{~h} /$ day, as reported by Hass and coworkers in 1994, newborn rats had lower weights, with delayed physical growth, and could perform simple tasks similar to other rats; nevertheless, they could not perform tasks that were more complex (58). In a study by Malek and coworkers on male and female rats and mice, oral administration of NMP has been reported to have "no observable adverse effect level" (NOAEL) up to 6000 and $18000 \mathrm{ppm}$ for male and female rats, respectively, with $2500 \mathrm{ppm}$ being the limit for mice. In higher doses, NMP causes a decrease in body weight (54). In another study on rats and mice by Malley and coworkers, rats fed 15000 ppm NMP for 2 years showed loss of body weight, nephropathy, and possible oncogenicity; and mice fed $7200 \mathrm{ppm}$ of NMP showed liver-related pathologies. Their findings suggest that the NOAEL for rats is 5000 ppm; and for male and female mice, 600 and 1200 ppm, respectively (55). In two studies by Saillenfait and coworkers on rats, it has been shown that a dose of $500 \mathrm{mg} / \mathrm{kg} /$ day of orally administered NMP and $120 \mathrm{ppm}$ of NMP administered by the inhalation route can damage the fetus $(59,60)$. In a recent study by Saillenfait and coworkers, it has been shown that two metabolites of NMP (5-hydroxy-Nmethyl-2-pyrrolidone and 2-hydroxy-Nmethylsuccinimide) have no significant effects on embryos, whereas another metabolite (Nmethylsuccinimide) has lower toxicity in comparison with NMP (61). In a more recent work by Sitarek and Stetkiewicz, it has been shown that daily exposure to $1000 \mathrm{mg} / \mathrm{kg}$ of NMP causes infertility in male rats (62).

A list of the $\mathrm{LD}_{50}$ values in different animals for NMP and other common pharmaceutical cosolvents is presented in Table 3 .

\section{Human Studies}

In a study by Ochiai in 1981, an increase has been reported in the hemoglobin amount and leukocyte count of the peripheral blood of workers exposed to vapors of a mixture of $\mathrm{N}$-dimethylacetamide and NMP (64). In addition, there has been an elevation in the levels of glutamate pyruvate transaminase and glutamate oxaloacetate transaminase during the ensuing two years of surveillance (64).

In a case report in 1996 by Gina et al., a 23year-old woman was reported to deliver a stillborn fetus after chronic and acute laboratory exposure to NMP during pregnancy (65). NMP was considered responsible for the outcome, because no other possible risk factor was present that could have caused the stillbirth. In addition, studies on animals had shown that NMP is a fetotoxic solvent (65), thus Gina and coworkers concluded that NMP might be fetotoxic in humans also (65). However, in a reply to this case report in 1997, these conclusions have been questioned and rejected by Bower (66).

In a study on six healthy male volunteers carried out in 1997 to evaluate the irritationproducing effect of NMP, it has been reported that exposure of eight hours per day to NMP, in the range of $10-50 \mathrm{mg} / \mathrm{m}^{3}$, does not cause nose, eye, and airway irritations (67).

However, the authors also discussed that their findings were not in agreement with a previous report in which considered an exposure to 3-6 $\mathrm{mg} / \mathrm{m}^{3}$ of NMP at a rate of $8 \mathrm{~h}$ /day was considered unacceptable due to the emergence of eye irritation $(68,69)$.

Further studies were conducted to measure the amount of evaporated NMP that is absorbed through the cutaneous and inhalation routes as a consequence of experimental or workplace exposures $(52,67,70,78)$. Akesson and Paulsson have concluded that exposure to 10,25 , and 50 $\mathrm{mg} / \mathrm{m}^{3} \mathrm{NMP}$ does not cause eye, nose, and airway irritation (66). Bader and coworkers have concluded that workplace exposure to NMP does not cause any health complaints, except in the case of persons not using personal health-protecting equipments (69). 


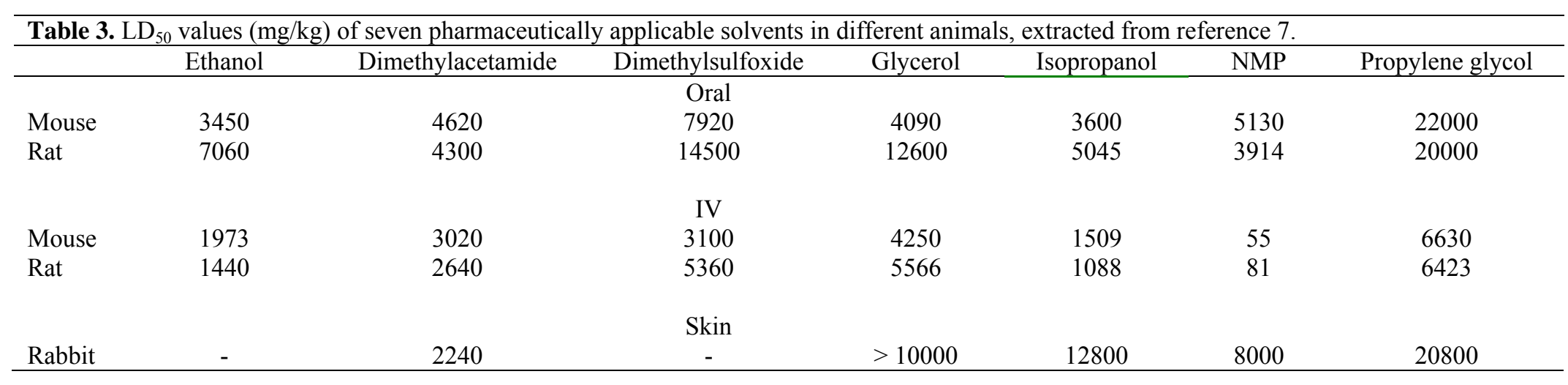

In another study, Bader and coworkers have concluded that a significant amount of NMP can be taken up from the vapor phase after dermal exposure to the vapors (70). After evaluating the possible effects of NMP exposure in the workplace on human health, Nishimura et al. concluded that there is no significant changes in human physiology (71).

The common side effects and acute toxicity signs of the pharmaceutically applicable solvents, including NMP, in addition to their mutagenicity, carcinogenicity, and teratogenicity data are listed in Table 4. Careful review of the data shows that NMP is an acceptable pharmaceutical solvent and its side effects/possible toxicity is comparable to those of other common cosolvents.

\section{REGULATORY STATUS}

NMP is listed in a number of pharmacopeias. A monograph in the European Pharmacopeia is dedicated to NMP (74), and it is cited in the reagents list of the United States Pharmacopeia/National Formulary (75) and the British Pharmacopeia (76). The United States Food and Drug Administration (FDA) has approved a daily exposure of $5.30 \mathrm{mg}$ /day for NMP and has classified it as a class- 2 solvent. NMP is also approved by the FDA as a constituent in medical devices and is included in the list of indirect additives in food-contact materials $(45,77)$.

\section{CONCLUSIONS AND FUTURE PERSPECTIVES}

NMP is a strong solubilizing agent and is used in controlled-released delivery systems comprising parenteral formulations of veterinary drugs. The available veterinary formulations that use NMP as an excipient are florfenicol IV solution (an antibiotic) and doxycycline gel for the treatment and control of periodontal diseases.

The formulations for human use include a controlled-release gel for the subcutaneous injection of leuprolide acetate and a subgingival form of doxycycline hyclate, both of which contain NMP. This solvent can be used as a cosolvent in parenteral formulations and as an enhancer in topical dosage forms. In addition, it can be used for crystallization of drugs, in pharmaceutical analysis, and as a drug-delivery agent. It is biodegradable and can be easily recycled. Therefore, environment pollution considerations are fewer and it is more compatible with greenchemistry guidelines. 


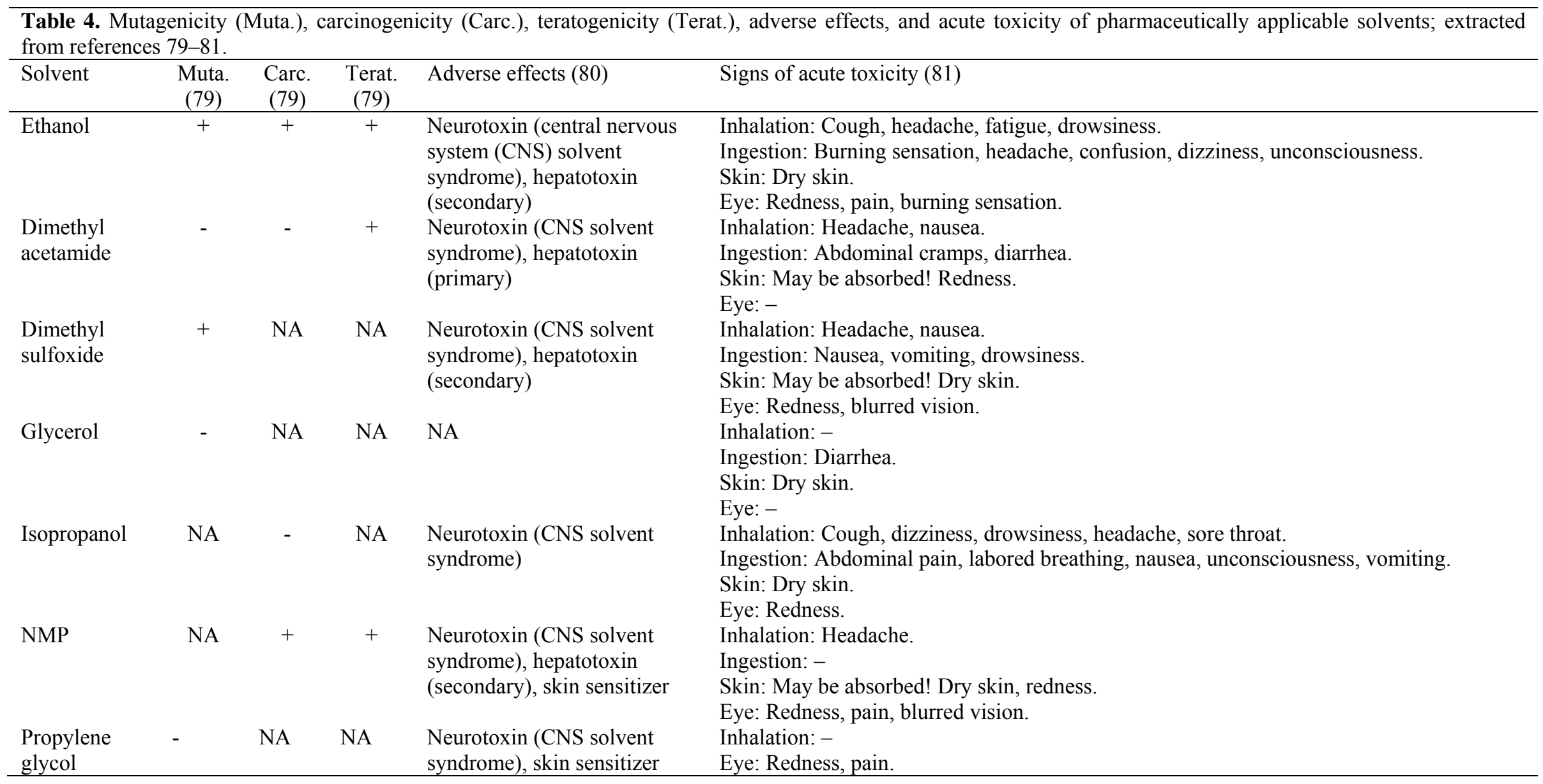

Every compound has its limitations in terms of application because it may induce toxicity by intake through different routes. These limitations might be ignorable (for water) or life-threatening (for organophosphorus). Most pharmaceutical agents should be administered only when their benefits overcome their side effects, and all medicines should be given to patients in doses that are lower than the toxic levels.
This rule also should be considered for the amount of excipients (including cosolvents) used in the formulations. In this review a list of potential and possible adverse effects of pharmaceutically applicable solvents is presented. Almost every cosolvent has its own limitations in applications. Those with lower solubilizing power are less harmful and those with higher power are more harmful. 
NMP appears to have more solubilizing power than other solubilizers. It is a potent penetration enhancer. Also it is thermally stable. The safety of NMP under various conditions and with high doses and prolonged exposure needs more detailed studies. According to available studies on animals, lower doses of NMP can cause adverse and toxic effects on males, in comparison with females. In addition, exposure to high concentrations of NMP during pregnancy in rats can cause abnormalities in fetuses. Nevertheless, no significant and robust data about human subjects are available. It must be taken into account that ethanol, which is the most frequently used cosolvent, has teratogenic and carcinogenic potentials (78). However, caution must be applied in administering NMP to human subjects and studies that are more comprehensive are required to arrive at a decision about the teratogenicity, mutagenicity, or toxicity of NMP on human subjects. Another suggestion is that comprehensive studies on the toxic effects of the previously studied solvents should be undertaken on animal models.

Finally, it must be stressed that NMP can easily solubilize medicinal agents at lower quantities compared to other common cosolvents. This may be useful in applications where a small amount of cosolvent is required.

\section{ACKNOWLEDGMENT}

This work is dedicated to Professor Mohammad Barzegar-Jalali, Department of Pharmaceutics, Faculty of Pharmacy, Tabriz University of Medical Sciences, Tabriz, Iran, for his lifelong efforts toward pharmacy training in Iran.

\section{REFERENCES}

[1]. Denes F, Miko F, Gardos G, Kovacs M. Investigation of an energy saving lubricating oil refining process, 2. Recovery of N-methyl-2pyrrolidone by extraction with water. Magy Kem Lapja, 40:211-214, 1985.

[2]. Gardos G, Kovacs M, Kun-Szabo T, Denes F, Miko F. Investigation on energy conserving lubricating oil producing process. III. Recovery of the solvent N-methyl-2-pyrrolidone. Hungar $\mathrm{J}$ Ind Chem, 11:435-441, 1983.

[3]. Chow ST, Ng TL. The biodegradation of Nmethyl-2-pyrrolidone in water by sewage bacteria. Water Res, 17:117-118, 1983.
[4]. Strickley RG. Solubilizing excipients in oral and injectable formulations. Pharm Res, 21:201-230, 2004.

[5]. Radhika G, Venkatesan R, Kathiroli S. Nmethylpyrrolidone: Isolation and characterization of the compound from the marine sponge Clathria frondifera (class: Demospongiae). Indian J Mar Sci, 36:235-238, 2007.

[6]. Rubino, JT., Cosolvents and cosolvency, in Swarbrick, J.; Boylan, JC. (eds.), Encyclopedia of Pharmaceutical Technology. 2nd edition, Vol. 3, Marcel Decker Inc, New York, NY, pp 375-398, 1990.

[7]. ChemIDplus advanced. U.S. National Library of Medicine.

http://chem.sis.nlm.nih.gov/chemidplus/ (last accessed April 2010).

[8]. Tarantino R, Bishop E, Chen FC, Iqbal K, Malick AW. N-methyl-2-pyrrolidone as a cosolvent: Relationship of cosolvent effect with solute polarity and the presence of protondonating groups on model drug compounds. J Pharm Sci, 83:1213-1216, 1994.

[9]. Uch AS, Hesse U, Dressman JB. Use of 1methyl-pyrrolidone as a solubilizing agent for determining the uptake of poorly soluble drugs. Pharm Res, 16:968-971, 1999.

[10]. Bachhav YG, Date AA, Patravale VB. Exploring the potential of N-methyl pyrrolidone as a cosurfactant in the microemulsion systems. Int J Pharm, 326:186-189, 2006.

[11]. Sanghvi R, Narazaki R, Machatha SG, Yalkowsky SH. Solubility improvement of drugs using N-methyl pyrrolidone. AAPS PharmSciTech, 9:366-376, 2008.

[12]. Shrejder AV, Kravchenko ZA, Shen u Shen YK, Fateeva TV. Corrosion of steel with Nmethylpyrrolidone. Zashchita Metallov, 431436, 1992.

[13]. Vishnevskij AV, Konoplev VP, Kravchenko ZA, Shrejder AV, Shen-Ushen YK, Fateeva TV. Corrosivity of N-methylpyrrolidone during selective oil refining. Khimiya i Tekhnologiya Topliv i Masel, 12-13, 1992.

[14]. Smallwood, IM., Handbook of Organic Solvents Properties. Arnold, Hodder Headline Group, London, UK, 1996.

[15]. BASF, The Chemical Company, http://www2.basf.us/diols/bcdiolsnmp.html (last accessed September 2010).

[16]. Avdeef A. Solubility of sparingly-soluble ionizable drugs. Adv Drug Deliv Rev, 59:568590, 2007.

[17]. Xu WL, Mao F, Zhao HK, Wang YQ, Wang J. Solubility of anthracene in N,N- 
dimethyformamide, N,N-dimethylacetamide, and N-methyl-2-pyrrolidone. J Chem Eng Data, 52:553-554, 2007.

[18]. Wang Q, Xu H, Li X. Solubilities of 4carboxybenzaldehyde and 1,4benzenedicarboxylic acid in N-methyl-2pyrrolidone in the temperature range from (343.2 to 468.2) K. J Chem Eng Data, 50:243245, 2005.

[19]. Wei C, Lamey KA, Oh C. Carvedilol Pharmasolve Solvate. WIPO: WO 03/092626 A2, 2003.

[20]. Johnston A, Florence AJ, Kennedy AR. Hydrochlorothiazide N-methyl-2-pyrrolidone disolvate. Acta Crystallogr Sect E Struct Rep Online, 62: o5169-o5171, 2006.

[21]. Soltanpour S, Acree Jr WE, Jouyban A. Solubility of pioglitazone hydrochloride in aqueous solutions of ethanol, propylene glycol, and N-methyl-2-pyrrolidone at 298.2 K. AAPS PharmSciTech, 10:1153-1157, 2009.

[22]. Shayanfar A, Acree Jr WE, Jouyban A. Solubility of clonazepam, diazepam, lamotrigine, and phenobarbital in N-methyl-2pyrrolidone + water mixtures at 298.2 K. J Chem Eng Data, 54:2964-2966, 2009.

[23]. Li A, Yalkowsky SH. Predicting cosolvency. 1. Solubility ratio and solute log Kow. Ind Eng Chem Res, 37:4470-4475, 1998.

[24]. Jouyban A. Review of the cosolvency models for predicting solubility of drugs in watercosolvent mixtures. J Pharm Pharm Sci, 11:3258, 2008.

[25]. Shayanfar A, Fakhree MAA, Acree Jr WE, Jouyban A. Solubility of lamotrigine, diazepam and clonazepam in ethanol-water mixtures at 298.15 K. J Chem Eng Data, 54:1107-1109, 2009.

[26]. Shayanfar A, Acree Jr WE, Jouyban A. Solubility of lamotrigine, diazepam and clonazepam in propylene glycol + water mixtures at $298.15 \mathrm{~K}, \mathrm{~J}$ Chem Eng Data, 54:1153-1157, 2009.

[27]. Godavarthy SS, Yerramsetty KM, Rachakonda VK, Neely BJ, Madihally SV, Robinson Jr RL, Gasem KAM. Design of improved permeation enhancers for transdermal drug delivery. J Pharm Sci. 98:4085-4099, 2009.

[28]. Rachakonda VK, Yerramsetty KM, Madihally SV, Robinson Jr RL, Gasem KAM. Screening of chemical penetration enhancers for transdermal drug delivery using electrical resistance of skin. Pharm Res. 25:2697-2704, 2008.

[29]. Lee PJ, Langer R, Shastri VP. Role of n-methyl pyrrolidone in the enhancement of aqueous phase transdermal transport. J Pharm Sci, 94:912-917, 2005.

[30]. Fujii M, Bouno M, Fujita S, Yoshida M, Watanabe Y, Matsumoto M. Preparation of griseofulvin for topical application using $\mathrm{N}$ methyl-2-pyrrolidone. Biol Pharm Bull, 23:1341-1345, 2000.

[31]. Yang P, Ding XY, Gao S. Effects of penetration enhancers on skin permeation behavior of fluoxetine hydrochloride in vitro. Acad J Sec Milit Med Univ, 28:1252-1254, 2007.

[32]. Lee PJ, Ahmad N, Langer R, Mitragotri S, Prasad Shastri V. Evaluation of chemical enhancers in the transdermal delivery of lidocaine. Int J Pharm, 308:33-39, 2006.

[33]. Li X, Pan W, Ju C, Liu Z, Pan H, Zhang H, Nie S. Evaluation of Pharmasolve ${ }^{\circledR}$ corneal permeability enhancement and its irritation on rabbit eyes. Drug Deliv, 16:224-229, 2009.

[34]. Montenegro L, Bucolo C, Puglisi G. Enhancer effects on in vitro corneal permeation of timolol and acyclovir. Pharmazie, 58:497-501, 2003.

[35]. Zheng WW, Zhao L, Wei YM, Ye Y, Xiao SH. Preparation and the in vitro evaluation of nanoemulsion system for the transdermal delivery of granisetron hydrochloride. Chem Pharm Bull, 58, 1015-1019, 2010.

[36]. Yerramsetty KM, Neely BJ, Madihally SV, Gasem KAM. A skin permeability model of insulin in the presence of chemical penetration enhancer. Int J Pharm, 388:13-23, 2010.

[37]. Fujii M, Koizumi A, Kinoshita Y, Suzuki R, Nio J, Kondoh M, Watanabe Y. Effect of Nmethyl-2-pyrrolidone on the skin permeation of estradiol and levonorgestrel from adhesive strips prepared using Eudragit EPO. J Drug Deliv Sci Technol, 16:121-125, 2006.

[38]. Koizumi A, Fujii M, Kondoh M, Watanabe Y. Effect of N-methyl-2-pyrrolidone on skin permeation of estradiol. Eur J Pharm Biopharm, 57:473-478, 2004.

[39]. Babu RJ, Pandit JK. Effect of penetration enhancers on the transdermal delivery of bupranolol through rat skin. Drug Deliv, 12:165-169, 2005.

[40]. Kikwai L, Babu RJ, Prado R, Kolot A, Armstrong CA, Ansel JC, Singh M. In vitro and in vivo evaluation of topical formulations of Spantide II. AAPS PharmSciTech, 6: E565E572, 2005.

[41]. Bhatia KS, Singh J. Percutaneous absorption of LHRH through porcine skin: Effect of N-methyl 2-pyrrolidone and isopropyl myristate. Drug Dev Ind Pharm, 23:1111-1114, 1997.

[42]. Akhter SA, Barry BW. Absorption through human skin of ibuprofen and flurbiprofen. 
Effect of dose variation, deposited drug films, occlusion and the penetration enhancer $\mathrm{N}$ methyl-2-pyrrolidone. J Pharm Pharmacol, 37:27-37, 1985.

[43]. Sugibayashi K, Sakanoue C, Morimoto Y. Utility of topical formulations of morphine hydrochloride containing azone and N-methyl2-pyrrolidone. Sel Cancer Ther, 5:119-128, 1989.

[44]. Bell BE. Improving injection consistency using $\mathrm{N}$-methyl-2-pyrrolidone as a GC syringe wash. LC GC N Am, 25:572-580, 2007.

[45]. Miguel BS, Ghayor C, Ehrbar M, Jung RE, Zwahlen RA, Hortschansky P, Schmoekel HG, Weber FE. N-methyl pyrrolidone as a potent bone morphogenetic protein enhancer for bone tissue regeneration. Tissue Eng Part A, 15:29552963, 2009.

[46]. Saw CLL, Olivo M, Wohland T, Fu CY, Kho $\mathrm{KW}$, Soo KC, Sia Heng PW. Effects of Nmethyl pyrrolidone on the uptake of hypericin in human bladder carcinoma and co-staining with DAPI investigated by confocal microscopy. Technol Cancer Res Treat, 6:383-394, 2007.

[47]. Jeon SH, Xu P, MacK NH, Chiang LY, Brown L, Wang HL. Understanding and controlled growth of silver nanoparticles using oxidized Nmethyl-pyrrolidone as a reducing agent. J Phys Chem C, 114:36-40, 2010.

[48]. Bergin SD, Sun Z, Streich P, Hamilton J, Coleman JN. New solvents for nanotubes: Approaching the dispersibility of surfactants,. J Phys Chem C, 114:231-237, 2010.

[49]. Sitarek K, Kilanowicz A. Tissue distribution and excretion of N-methyl-2-pyrrolidone in male and female rats. Int J Occup Med Environ Health, 19:142-148, 2006.

[50]. Ursin C, Hansen CM, Van Dyk JW, Jensen PO, Christensen IJ, Ebbehoej J. Permeability of commercial solvents through living human skin. Am Ind Hyg Assoc J, 56:651-660, 1995.

[51]. Payan JP, Beydon D, Fabry JP, Boudry I, Cossec B, Ferrari E. Toxicokinetics and metabolism of $\mathrm{N}-(14 \mathrm{C})$ methylpyrrolidone in male Sprague-Dawley rats. A saturable NMP elimination process. Drug Metab Dispos, 30:1418-1424, 2002.

[52]. Carnerup MA, Spanne M, Jönsson BAG. Levels of N-methyl-2-pyrrolidone (NMP) and its metabolites in plasma and urine from volunteers after experimental exposure to NMP in dry and humid air. Toxicol Lett, 162:139-145, 2006.

[53]. Akesson B, Jönsson BAG. Major metabolic pathway for N-methyl-2-pyrrolidone in humans. Drug Metab Dispos, 25:267-269, 1997.
[54]. Malek DE, Malley LA, Slone TW, Elliott GS, Kennedy GL, Mellert W, Deckardt K, Gembardt C, Hildebrand B, Murphy SR, Bower DB, Wright GA. Repeated dose toxicity study (28 days) in rats and mice with $\mathrm{N}$ methylpyrrolidone (NMP). Drug Chem Toxicol, 20:63-77, 1997.

[55]. Malley LA, Kennedy GL, Elliott GS, Slone TW, Mellert W, Deckardt K, Kuttler K, Hildebrand B, Banton MI, Parod RJ, Griffiths JC. Chronic toxicity and oncogenicity of Nmethylpyrrolidone (NMP) in rats and mice by dietary administration. Drug Chem Toxicol, 24:315-338, 2001

[56]. Becci PJ, Knickerbocker MJ, Reagan EL, Parent RA, Burnette LW. Teratogenicity study of Nmethylpyrrolidone after dermal application to Sprague-Dawley rats. Fundam Appl Toxicol, 2:73-76, 1982.

[57]. Lee KP, Chromey NC, Culik R, Barnes JR, Schneider PW. Toxicity of N-methyl-2pyrrolidone (NMP): Teratogenic, subchronic, and two-year inhalation studies. Fundam Appl Toxicol, 9:222-235, 1987.

[58]. Hass U, Lund SP, Elsner J. Effects of prenatal exposure to $\mathrm{N}$-methylpyrrolidone on postnatal development and behavior in rats. Neurotoxicol Teratol, 16:241-249, 1994.

[59]. Saillenfait AM, Gallissot F, Langonné I, Sabaté JP. Developmental toxicity of N-methyl-2pyrrolidone administered orally to rats. Food Chem Toxicol, 40:1705-1712, 2002.

[60]. Saillenfait AM, Gallissot F, Morel G. Developmental toxicity of N-methyl-2pyrrolidone in rats following inhalation exposure. Food Chem Toxicol, 41:583-588, 2003.

[61]. Saillenfait AM, Sabaté JP, Gallissot F. Comparative developmental toxicities of the three major metabolites of N-methyl-2pyrrolidone after oral administration in rats. $\mathrm{J}$ Appl Toxicol, 27:571-581, 2007.

[62]. Sitarek K, Stetkiewicz J. Assessment of reproductive toxicity and gonadotoxic potential of N-methyl-2-pyrrolidone in male rats. Int $\mathrm{J}$ Occup Med Environ Health, 21:73-80, 2008.

[63]. Becci PJ, Gephart LA, Koschier FJ, Johnson WD, Burnette LW. Subchronic feeding study in beagle dogs of N-methylpyrrolidone. J Appl Toxicol, 3:83-86, 1983.

[64]. Ochiai S. Hygienic studies on workers engaged in producing synthetic heatresisting enamel wire. Mixed toxicity of $\mathrm{N}$-dimethylacetamide and N-methylpyrrolidone. Clinician, 45:327338, 1981. 
[65]. Solomon GM, Morse EP, Garbo MJ, Milton DK. Stillbirth after occupational exposure to Nmethyl-2-pyrrolidone. A case report and review of the literature. J Occup Environ Med, 38:705713, 1996.

[66]. Bower DB, Solomon GM, Morse EP, Garbo MJ. Letter to the editor: Stillbirth after occupational exposure to $\mathrm{N}$ - methyl-2 pyrrolidone. J Occup Environ Med, 39:393-394, 1997.

[67]. Akesson B, Paulsson K. Experimental exposure of male volunteers to $\mathrm{N}$-methyl-2-pyrrolidone (NMP): Acute effects and pharmacokinetics of NMP in plasma and urine. Occup Environ Med, 54:236-240, 1997.

[68]. Beaulieu HJ, Schmerber KR. M-Pyrol® (NMP) use in the microelectronics industry. Appl Occup Environ Hyg, 6:874-880, 1991.

[69]. Leira HL, Tiltnes A, Svendsen K, Vetlesen L. Irritant cutaneous reactions to N-methyl-2pyrrolidone (NMP). Contact Dermatitis, 27:148150, 1992.

[70]. Bader M, Rosenberger W, Rebe T, Keener SA, Brock TH, Hemmerling HJ, Wrbitzky R. Ambient monitoring and biomonitoring of workers exposed to N-methyl-2-pyrrolidone in an industrial facility. Int Arch Occup Environ Health, 79:357-364, 2006.

[71]. Nishimura S, Yasui H, Miyauchi H, Kikuchi Y, Kondo N, Takebayashi T, Tanaka S, Mikoshiba Y, Omae K, Nomiyama T. A cross-sectional observation of effect of exposure to N-methyl2-pyrrolidone (NMP) on workers' health. Ind Health, 47:355-362, 2009.

[72]. Laurent A, Mottu F, Chapot R, Zhang JQ, Jordan O, Rüfenacht DA, Doelker E, Merland JJ. Cardiovascular effects of selected watermiscible solvents for pharmaceutical injections and embolization materials: A comparative hemodynamic study using a sheep model. PDA J Pharm Sci Technol, 61:64-74, 2007.

[73]. NCBI Database. U.S. National Library of Medicine.

http://www.ncbi.nlm.nih.gov/sites/entrez?db=pc compound $\& \mathrm{cmd}=$ Link $\&$ LinkName $=$ pccompoun d_pcassay\&from_uid=13387 (last accessed April 2010).

[74]. European Pharmacopoeia (EP), Council of Europe, Strasbourg, 2007.

[75]. United States Pharmacopoeia-National Formulary (USP 32-NF 27), United States Pharmacopeia Convention, Rockville, MD, 2008.

[76]. British Pharmacopoeia, The Stationery Office, London, 2009.

[77]. US Food and Drug Administration. http://www.fda.gov/(last accessed September 2010).

[78]. Bader M, Wrbitzky R, Blaszkewicz M, Schäper M, Van Thriel C. Human volunteer study on the inhalational and dermal absorption of N-methyl2-pyrrolidone (NMP) from the vapour phase. Arch Toxicol, 82:13-20, 2008.

[79]. Toxicology Data Network. U.S. National Library of Medicine. http://toxnet.nlm.nih.gov/ (last accessed April 2010).

[80]. Brown JA. Haz-Map: Information on Hazardous Chemicals and Occupational Diseases. U.S. National Library of Medicine. http://hazmap.nlm.nih.gov/ (last accessed April 2010).

[81]. The National Institute for Occupational Safety and Health. Centers for Disease Control and Prevention. http://www.cdc.gov/NIOSH/ (last accessed April 2010).

[82]. Breon TL, Paruta AN, Solubility profiles for several barbiturates in hydroalcoholic mixtures, J Pharm Sci, 59:1306-1313, 1970. 